\title{
Bioactive compounds, processing quality and yield of colored flesh potato clones
}

\author{
Francieli Fatima Cima ${ }^{1} \mathbb{D}$; Elisa dos S Pereira ${ }^{1} \mathbb{D}$; Marina V Schiavon ${ }^{1} \mathbb{D}$; Priscila C Munhoz ${ }^{1} \mathbb{D}$; Emerson \\ A Lenz ${ }^{1} \mathbb{D}$; Daiana D Wolter ${ }^{1} \mathbb{D}$; Tuane A da Silva ${ }^{1} \mathbb{D}$; Fernanda $Q$ Azevedo ${ }^{2} \mathbb{D}$; Márcia Vizzotto ${ }^{2} \mathbb{D}$; Arione da $S$ \\ Pereira ${ }^{2} \mathbb{D}$
}

1'Universidade Federal de Pelotas (UFPel), Pelotas-RS, Brasil; franci_cima@yahoo.com.br; lisaspereira@gmail.com; marinavighi@gmail.

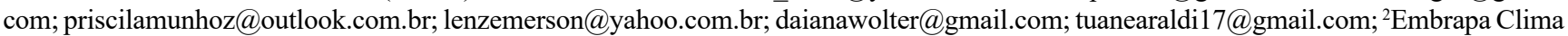
Temperado, Pelotas-RS, Brasil; fernanda.azevedo@embrapa.br; marcia.vizzotto@embrapa.br; arione.pereira@embrapa.br

\begin{abstract}
Colored flesh potatoes contain high concentrations of phytochemicals, such as phenolic acids, anthocyanins and carotenoids, which have therapeutic effects and promoters of human health. The objective of the study was to evaluate the concentration of bioactive compounds and industrial quality and yield traits of potato tubers. Four experiments were carried out in Pelotas-RS. In 2012 and 2013, tuber yield traits were evaluated and in 2014 and 2015, the bioactive compounds (phenolic compounds, anthocyanins and carotenoids), antioxidant activity and industrial quality traits [glucose content, dry matter (\%) and frying color] were assessed. Clones C2715-01-09, C2721-22-09 and C2743-01-09, having fully pigmented purple flesh presented high concentrations of bioactive compounds and high antioxidant capacity and reasonable processing quality traits and yield potential. Clone C2743-09-09 with white flesh interspersed with purple was the most productive and had good processing attributes, but showed lower levels of bioactive compounds and moderate antioxidant activity when compared to completely purple clones.
\end{abstract}

Keywords: Solanum tuberosum, antioxidant, special potatoes.

\section{RESUMO}

Compostos bioativos, qualidade industrial e rendimento de clones de batata de polpa colorida

Batatas com polpa colorida contêm elevadas concentrações de fitoquímicos, tais como ácidos fenólicos, antocianinas e carotenoides, que apresentam efeitos terapêuticos e promotores da saúde humana. $\mathrm{O}$ objetivo deste estudo foi avaliar a concentração de compostos bioativos, e caracteres de qualidade industrial e de rendimento de tubérculos de batata de polpa colorida. Quatro experimentos foram realizados em Pelotas-RS. Em 2012 e 2013, avaliaram-se os caracteres de rendimento de tubérculos, e em 2014 e 2015, avaliaram-se os compostos bioativos (compostos fenólicos, antocianinas e carotenoides), atividade antioxidante e caracteres de qualidade industrial (teor de glicose, porcentagem de massa seca e cor de fritura). Os clones C2715-01-09, C2721-22-09 e C274301-09, de polpa roxa intensa, apresentaram elevadas concentrações de compostos bioativos e alta capacidade antioxidante, e razoáveis características de processamento e potencial produtivo. O clone C2743-09-09, de polpa branca entremeada com roxo, foi o mais produtivo e mostrou bons atributos de processamento, porém teores inferiores de compostos bioativos e moderada atividade antioxidante quando comparado aos clones completamente roxos.

Palavras-chave: Solanum tuberosum, antioxidante, batatas especiais.

\section{Received on February 28, 2019; accepted on March 2, 2020}

$\mathrm{P}$ otato (Solanum tuberosum) is the third most important crop in the world in terms of human consumption (CIP, 2018) and the second vegetable of highest economic importance in Brazil (IBGE, 2018). In addition to carbohydrates, it is an excellent source of vitamins, minerals and phytochemicals, such as phenolic and carotenoid compounds (Navarre et al., 2016). These phytochemicals are highly desirable in the diet, as they have therapeutic and health-promoting effects and can act as antioxidants, anti-mutagens, anti-proliferators and anti-inflammatories, playing a key role in the prevention and/or treatment of chronic diseases (Liu, 2013).

In recent years, with the increasing appreciation of products with functional potential, consumers have shown attention in the health benefits obtained through food. In view of this, consumer perception, unconventional potatoes, that is, potatoes with a multiplicity of skin colors, flesh color and tuber shape are gaining space in the market in several countries. These potatoes have higher concentrations of antioxidant compounds than conventional cultivars and their consumption can increase the intake of compounds with benefits to human health (Brown et al., 2005). 
Two classes of compounds confer color to the tubers and have antioxidant properties. The red and purple colors of the flesh and/or skin, in varying shades, are due to anthocyanins, which are phenolic pigments (Liu, 2013), while the yellow to orange pigmentation is due to the concentration of carotenoids (Brown et al., 1993). It has been reported that anthocyanins present in potatoes can protect against prostate cancer (Reddivari et al., 2007) and breast cancer (Thompson et al., 2009). The pro-vitamin A activity of carotenoids is well known, however, in potatoes, only small amounts of $\beta$-carotene are found (Brown et al., 1993). The most abundant carotenoids, lutein and zeaxanthin, found in yellow and orange fleshed potatoes, respectively, are important photoprotective compounds of the human retina (Liu, 2013).

Brazilian potato industry is growing very well and the main processed products come from white/cream fleshed cultivars, which have lower concentrations of bioactive compounds. The use of colored flesh potatoes could be an alternative for the industry, especially for chipping. The intense and attractive coloring, differentiated flavor and higher functional value of the product could constitute a new market niche. In the United States and Europe, there is already a market space for colored flesh potatoes (Lachman et al., 2016), but in Brazil there is only an occasional supply of this product.

Considering the aspect of innovation and market potential of colored pulp potatoes, the Embrapa Potato Breeding Program began to generate progenies, with the introgression of genes of the red and purple flesh traits into adapted germplasm. From this effort, clones were selected that needed to be evaluated for the concentration of bioactive compounds, processing quality and tuber yield traits, which were the objectives of this study.

\section{MATERIAL AND METHODS}

Twelve colored flesh potato clones from the Embrapa Potato Breeding Program (C2715-01-09, C2715-08-09,
C2715-22-09, C2717-04-09, C271807-09, C2718-24-09, C2719-11-09, C2721-22-09, C2722-12-09, C274301-09, C2743-09-09 and C2743-16-09), were compared to conventional cultivars Macaca (2012 crop season), Asterix (2013 crop season) and BRS Ana (2014 and 2015 crop seasons). 'Macaca' was used to select for earliness and 'Asterix' and 'BRS Ana' to assess clones for tuber yield and industrial quality traits.

The experiments were carried out in fields of Embrapa Clima Temperado, in Pelotas, RS ( $31^{\circ} 42^{\prime}$ S, $52^{\circ} 24^{\prime} \mathrm{W}$, altitude $50 \mathrm{~m}$ ), in autumn crop seasons of 2012 , 2013, 2014 and 2015. According to Köppen, the climate of the region is humid subtropical of the Cfa type. Weather conditions, in general, were typical in the season crops. The randomized complete block design, with three replications was used. Each plot consisted of a 6-meter long row, with 20 plants spaced $0.80 \mathrm{~m}$ between rows and $0.30 \mathrm{~m}$ between plants, with $4.80 \mathrm{~m}^{2}$ useful area. Cultural and phytosanitary treatments followed recommendations for the crop in the region.

In autumn season crops, years 2012 and 2013, the harvested tubers of each plot were graded and evaluated on the yield traits: total tuber mass ( $\mathrm{kg}$ plot $\left.^{-1}\right)$; mass of marketable tubers $(\mathrm{kg}$ plot $^{-1}$ ); average tuber mass, obtained by dividing the total mass by the total number of tubers ( $\mathrm{g}$ tuber $\left.{ }^{-1}\right)$; and mass of marketable tubers (\%). The yields were transformed into $\mathrm{t} \mathrm{ha}^{-1}$. In 2012, 90 days after planting, the vegetative development cycle of the plants in each plot was assessed, using a nine-point scale of scores, with 1 attributed to the late cycle and 9 to the early cycle.

In autumn season crops, years 2014 and 2015, the clones were evaluated for the concentration of bioactive compounds (phenolic compounds, anthocyanins and carotenoids) and antioxidant activity, pulp color, pulp color parameters $\left(\mathrm{L}^{*}, \mathrm{C}^{*}\right.$ and $\left.\mathrm{h}^{\circ}\right)$ and industrial quality [glucose content, dry matter (\%) and chips color]. Except for total carotenoid concentration and dry mass content, assessed only in the 2014 crop season, flesh color and chip color parameters were evaluated in the 2015 crop season, the other traits were evaluated in both experiments.

To analyze the bioactive compounds, samples of four tubers of each plot were used and evaluated in duplicate. From the central part of each tuber, a peeled slice $1 \mathrm{~cm}$ thick was removed, which was cut radially.

The total phenolic compound concentration was quantified according to the method adapted from Swain \& Hillis (1959). The absorbance at 725 $\mathrm{nm}$ was read on a spectrophotometer. Chlorogenic acid was used as a reference for the calibration curve (0-0.35 $\left.\mathrm{mg} \mathrm{mL}^{-1}\right)$ and the results were expressed in $\mathrm{mg}$ of chlorogenic acid equivalent per $100 \mathrm{~g}$ fresh sample.

The total anthocyanin concentration was quantified according to the method adapted from Fuleki \& Francis (1968). The determination was made in a spectrophotometer with an absorbance measurement performed at $535 \mathrm{~nm}$ wavelength. Cyanidin-3-glycoside was used as reference for the calibration curve $\left(0-0.04 \mathrm{mg} \mathrm{mL}^{-1}\right)$ and the results were expressed in $\mathrm{mg}$ of cyanidin-3glycoside per $100 \mathrm{~g}$ fresh sample.

The total carotenoid concentration was quantified by the method adapted from Talcott \& Howard (1999). Readings were taken on a spectrophotometer at 470 $\mathrm{nm}$. $\beta$-carotene was used as reference for the calibration curve $\left(0-0.01 \mathrm{mg} \mathrm{mL}^{-1}\right)$ and the results were expressed in $\mathrm{mg}$ of $\beta$-carotene equivalent per $100 \mathrm{~g}$ fresh sample.

The antioxidant activity was determined by the method adapted from Brand-Williams et al. (1995), using the stable radical 2,2-diphenyl1 - picrilhhydrazyl (DPPH). Absorbance readings were performed on a spectrophotometer at $515 \mathrm{~nm}$ wavelength. Trolox was used as reference for the calibration curve (0-0.8 $\left.\mathrm{mg} \mathrm{mL}^{-1}\right)$ and the results were expressed in $\mu \mathrm{g}$ of trolox equivalent per $\mathrm{g}$ of fresh sample.

The flesh color of fresh tubers was determined using the Minolta colorimeter, with the determination of $\mathrm{L}^{*} \mathrm{a}^{*} \mathrm{~b}^{*}$ coordinates. From the values of $a^{*}$ and $b^{*}$, the angle hue $\left(h^{\circ}\right)$ and Chroma $\left(\mathrm{C}^{*}\right)$ were calculated. For this analysis, the same tubers used to evaluate the bioactive compounds were 
used.

The reducing sugar content was assessed based on glucose, using a sample of three healthy tubers with no physiological and/or mechanical defects of each plot. Samples were evaluated in duplicate, according to the SomogyiNelson method (Nelson, 1944). The results were expressed in fresh mass \%.

The dry mass content was determined using a $5 \mathrm{~g}$ sample of potato cut into cubes from the central part of three tubers, in triplicate, dried in a vacuum oven at $70^{\circ} \mathrm{C}$ for $6 \mathrm{~h}$, according to the Association of Official Analytical Chemists method (AOAC, 1995).

The frying quality of the clones was evaluated using chips prepared from samples of ten tubers per plot. Chip color assessment was carried out by three evaluators, using a visual 9-point scale, adapted from the American Potato Chip and Snack Food Association, in which scores close to 1 are desirable and attributed to light color and 9 to dark color (Douches et al., 1996).

Normality of the data was checked using the Shapiro-Wilk test. The concentration of total anthocyanins was transformed by $\log 10(\mathrm{x})$, to meet the assumption of normality. Subsequently, the obtained data from two years (anthocyanins, phenolic compounds, antioxidant activity and glucose) were submitted to joint variance analysis, in a $13 \times 2$ factorial scheme, assuming the effects of genotype and year as fixed, while the other data, evaluated for only one crop, were submitted to individual variance analysis. Tuber yield traits were subjected to individual analysis of variance because the check cultivars were different. Means were grouped by the Scott-Knott test at $5 \%$ probability of error, using the Genes software.

\section{RESULTS AND DISCUSSION}

\section{2 and 2013 evaluations}

The individual variance analysis for yield and vegetative development cycle traits revealed significant $(p \leq 0.05)$ difference among genotypes for all traits in the two crop years.

In the 2012 crop season, evaluating mass of marketable tubers, the clones were grouped into three groups (Table 1). The upper group consisted of clones C2718-24-09, C2743-09-09 and C274301-09, with marketable yields above $25 \mathrm{tha}^{-1}$. These three clones also stood out in terms of total tuber mass, with yields higher than $27 \mathrm{t} \mathrm{ha}^{-1}$. Two of the most productive clones, C2718-24-09 and C2743-09-09 and C2717-04-09 had the largest tubers, with an average tuber mass between 93.95 and 104.12 g. For mass of marketable tubers, total tuber mass and average tuber mass, the cultivar Macaca was in the lower group.

Evaluating mass of marketable tubers (\%), clones C2718-24-09, C2743-09-09, C2743-01-09, C271704-09, C2715-08-09, C2715-01-09, C2721-22-09 and C2719-11-09 formed the upper group. Cultivar Macaca and clones C2722-12-09 and C2715-22-09 comprised the intermediate group.

Regarding the vegetative development cycle, three groups were formed. Clones C2718-24-09, C271501-09, C2719-11-09, C2718-07-09, C2743-16-09, C2722-12-09 and C271522-09 and cultivar Macaca composed the early cycle group. However, among the earliness ones, only clone C2718-2409 showed a high mass of marketable tubers.

In the 2013 crop experiment, in relation to the mass of marketable tubers, clones were grouped into three groups. Clone C2743-09-09 showed the highest yield, $29 \mathrm{tha}^{-1}$. The intermediate group was made up of clones $\mathrm{C} 2718-24-$ 09, C2721-22 09, C2715-08-09, C271501-09 and C2717-04-09 and the cultivar Asterix. Regarding total tuber mass, clones C2743-09-09, C2718-24-09, C2721-22-09, C2715-08-09, C2715-0109, C2719-11-09 and C2743-16-09 and the cultivar Asterix stood out, with total yield between 24.92 and $31.72 \mathrm{t} \mathrm{ha}^{-1}$.

About average tuber mass, clones C2743-09-09 and C2717-04-09 produced tubers with the highest mass, 89.58 and $97.22 \mathrm{~g}$, respectively. Cultivar Asterix and clones C2721-22-09, C2715-08-09, C2715-01-09 and C271522-09 constituted the second top group. In relation to mass of marketable tubers (\%), clones C2743-09-09, C2721-22-09, C2715-01-09 and C2717-04-09 stood out, with a value above $88 \%$. Clones
C2718-24-09, C2715-08-09 and C271522-09 and the cultivar Asterix formed the second group.

Bearing in mind that yield and size of tubers produced in the autumn crop season tend to be lower due to the lower availability and efficiency of solar radiation use (Bisognin et al., 2008), clones that presented marketable yield equal or superior to 'Asterix', which is the most planted red skin cultivar in Brazil and the base for the national frozen French fry industry, may be considered promising.

\section{4 and 2015 evaluations \\ Bioactive compounds and pulp color}

The joint analysis of variance for anthocyanins, phenolic compounds and antioxidant activity revealed significance $(\mathrm{p} \leq 0.05)$ for genotype $\mathrm{x}$ year interaction for total anthocyanins concentration. For other traits genotype $x$ year interaction was not significant. So, for the anthocyanins, the results were discussed separately each year.

The individual variance analysis for total carotenoid concentration and flesh color parameters $\left(\mathrm{L}^{*}, \mathrm{C}^{*}\right.$ and $\left.\mathrm{h}^{\circ}\right)$ revealed significant $(\mathrm{p} \leq 0.05)$ differences for genotype, but only for the flesh color parameters.

In relation to anthocyanins, in 2014, the content varied from 14.47 to 110.07 mg cyanidin 3-glycoside (C3G) per 100 $\mathrm{g}$ fresh mass $^{-1}\left(\mathrm{FM}^{-1}\right)$ in purple fleshed tubers and from 10.41 to $55.74 \mathrm{mg} \mathrm{C} 3 \mathrm{G}$ per $100 \mathrm{~g} \mathrm{FM}^{-1}$ in red fleshed tubers, while in 2015 , concentrations were lower, ranging from 12.01 to $75.31 \mathrm{mg}$ $\mathrm{C} 3 \mathrm{G}$ per $100 \mathrm{~g}^{-1} \mathrm{FM}^{-1}$ in purple fleshed tubers and 5.80 to $31.98 \mathrm{mg} \mathrm{C} 3 \mathrm{G}$ per $100 \mathrm{~g} \mathrm{FM}^{-1}$ in red fleshed tubers, showing high variation among clones and year of cropping (Table 2).

In addition to the genetic makeup, several environmental factors can influence the biosynthesis of bioactive compounds. Stress signs such as low temperature and high light intensity have been reported to induce anthocyanin biosynthesis (Sulc et al., 2017). The highest concentrations of anthocyanins are found in immature tubers, whereas during tuber development, a decrease in the concentration of these compounds is 
observed, which is consistent with the expression of most genes that decrease as the tubers reach maturity (Navarre et al., 2013; Payyavula et al., 2013). The higher anthocyanin concentrations in the 2014 crop than in the 2015 crop can be attributed to the lower temperatures from 70 days after planting, in 2014, a period coinciding with the tuber filling phase.

Table 1. Means of yield traits and vegetative cycle of 12 colored flesh potato clones and two conventional cultivars, in autumn crops 2012 and 2013. Pelotas, Embrapa, 2020.

\begin{tabular}{|c|c|c|c|c|c|}
\hline \multirow[t]{2}{*}{ Clone/cultivar } & $\begin{array}{c}\text { MTY } \\
\left(\mathbf{t} \mathbf{h a}^{-1}\right)^{1}\end{array}$ & 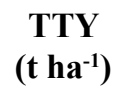 & $\begin{array}{c}\mathbf{A T M} \\
\text { (g) }\end{array}$ & $\begin{array}{l}\text { MT } \\
(\%)\end{array}$ & Cycle $^{2}$ \\
\hline & \multicolumn{5}{|c|}{2012} \\
\hline C2718-24-09 & $27.83 \mathrm{a}^{3}$ & $29.27 \mathrm{a}$ & $98.44 \mathrm{a}$ & $95.15 \mathrm{a}$ & $5.7 \mathrm{a}$ \\
\hline C2743-09-09 & $25.93 \mathrm{a}$ & $27.81 \mathrm{a}$ & $104.12 \mathrm{a}$ & $92.84 \mathrm{a}$ & $5.0 \mathrm{~b}$ \\
\hline C2743-01-09 & $25.89 \mathrm{a}$ & $28.79 \mathrm{a}$ & $77.81 \mathrm{~b}$ & $89.75 \mathrm{a}$ & $3.0 \mathrm{c}$ \\
\hline C2717-04-09 & $20.77 \mathrm{~b}$ & $22.72 \mathrm{~b}$ & $93.95 \mathrm{a}$ & $91.24 \mathrm{a}$ & $5.0 \mathrm{~b}$ \\
\hline C2715-08-09 & $20.75 \mathrm{~b}$ & $23.27 \mathrm{~b}$ & $76.32 \mathrm{~b}$ & $89.27 \mathrm{a}$ & $3.7 \mathrm{c}$ \\
\hline C2715-01-09 & $20.45 \mathrm{~b}$ & $23.26 \mathrm{~b}$ & $83.72 \mathrm{~b}$ & $86.50 \mathrm{a}$ & $6.0 \mathrm{a}$ \\
\hline C2721-22-09 & $19.83 \mathrm{~b}$ & $21.73 \mathrm{~b}$ & $87.72 \mathrm{~b}$ & $91.02 \mathrm{a}$ & $5.3 \mathrm{~b}$ \\
\hline C2719-11-09 & $17.64 \mathrm{~b}$ & $20.63 \mathrm{~b}$ & $71.54 \mathrm{~b}$ & $85.45 \mathrm{a}$ & $7.7 \mathrm{a}$ \\
\hline C2718-07-09 & $12.93 \mathrm{c}$ & $19.17 \mathrm{c}$ & $50.86 \mathrm{c}$ & $55.29 \mathrm{c}$ & $6.3 \mathrm{a}$ \\
\hline C2743-16-09 & $12.65 \mathrm{c}$ & $23.95 \mathrm{~b}$ & $51.32 \mathrm{c}$ & $52.62 \mathrm{c}$ & $6.7 \mathrm{a}$ \\
\hline Macaca & $9.81 \mathrm{c}$ & $14.77 \mathrm{~d}$ & $40.51 \mathrm{c}$ & $64.50 \mathrm{~b}$ & $8.0 \mathrm{a}$ \\
\hline C2722-12-09 & $8.85 \mathrm{c}$ & $13.40 \mathrm{~d}$ & $59.39 \mathrm{c}$ & $65.90 \mathrm{~b}$ & $6.0 \mathrm{a}$ \\
\hline C2715-22-09 & $8.72 \mathrm{c}$ & $12.25 \mathrm{~d}$ & $59.32 \mathrm{c}$ & $69.11 \mathrm{~b}$ & $7.0 \mathrm{a}$ \\
\hline Mean & 17.85 & 21.62 & 73.46 & 79.13 & 5.80 \\
\hline CV $(\%)$ & 20.58 & 17.03 & 13.43 & 7.01 & 19.47 \\
\hline \multicolumn{6}{|c|}{2013} \\
\hline C2743-09-09 & $29.02 \mathrm{a}$ & $31.72 \mathrm{a}$ & $89.58 \mathrm{a}$ & $91.55 \mathrm{a}$ & - \\
\hline C2718-24-09 & $23.69 \mathrm{~b}$ & $28.92 \mathrm{a}$ & $60.42 \mathrm{c}$ & $82.04 \mathrm{~b}$ & - \\
\hline C2721-22-09 & $23.27 \mathrm{~b}$ & $26.33 \mathrm{a}$ & $73.59 \mathrm{~b}$ & $88.27 \mathrm{a}$ & - \\
\hline C2715-08-09 & $23.00 \mathrm{~b}$ & $26.96 \mathrm{a}$ & $69.16 \mathrm{~b}$ & $85.21 \mathrm{~b}$ & - \\
\hline C2715-01-09 & $22.30 \mathrm{~b}$ & $25.05 \mathrm{a}$ & $77.21 \mathrm{~b}$ & $89.25 \mathrm{a}$ & - \\
\hline Asterix & $20.89 \mathrm{~b}$ & $27.00 \mathrm{a}$ & $73.58 \mathrm{~b}$ & $77.34 \mathrm{~b}$ & - \\
\hline C2717-04-09 & $18.88 \mathrm{~b}$ & $20.38 \mathrm{~b}$ & $97.92 \mathrm{a}$ & $92.66 \mathrm{a}$ & - \\
\hline C2719-11-09 & $17.74 \mathrm{c}$ & $24.92 \mathrm{a}$ & $62.26 \mathrm{c}$ & $71.03 \mathrm{c}$ & - \\
\hline C2715-22-09 & $14.75 \mathrm{c}$ & $17.99 \mathrm{~b}$ & $72.76 \mathrm{~b}$ & $81.67 \mathrm{~b}$ & - \\
\hline C2722-12-09 & $14.50 \mathrm{c}$ & $21.50 \mathrm{~b}$ & $55.87 \mathrm{c}$ & $67.75 \mathrm{c}$ & - \\
\hline C2743-01-09 & $14.43 \mathrm{c}$ & $22.13 \mathrm{~b}$ & $52.76 \mathrm{c}$ & $64.37 \mathrm{c}$ & - \\
\hline C2718-07-09 & $12.13 \mathrm{c}$ & $21.48 \mathrm{~b}$ & $40.82 \mathrm{~d}$ & $55.67 \mathrm{~d}$ & - \\
\hline C2743-16-09 & $10.46 \mathrm{c}$ & $26.67 \mathrm{a}$ & $45.37 \mathrm{~d}$ & $39.29 \mathrm{e}$ & - \\
\hline Mean & 18.85 & 24.70 & 67.02 & 75.85 & \\
\hline CV $(\%)$ & 10.96 & 8.48 & 13.86 & 7.00 & - \\
\hline
\end{tabular}

${ }^{1} \mathrm{MTY}=$ marketable tuber yield; TTY $=$ total tuber yield; ATM $=$ average tuber mass (obtained dividing the total yield by the total number of tubers); $\mathrm{MT}=$ percent of marketable tuber yield; ${ }^{2}$ Notes close to 1 denote late cycle clones and notes close to 9 early cycle; ${ }^{3}$ Means followed by same letters in the column, belong to the same group by the Scott-Knott test, $5 \%$ probability. clones for anthocyanin in the 2015 crop, remained in 2014, except for C271522-09. This clone together with C271824-09, C2743-16-09 and C2719-11-09 made up the second group. The cultivar BRS Ana and the clone C2718-07-09 formed the penultimate group, with concentrations close to $5 \mathrm{mg} \mathrm{C} 3 \mathrm{G}$ per $100 \mathrm{~g} \mathrm{FM}^{-1}$.

Regarding means of phenolic compound, they varied from 115.92 to $160.15 \mathrm{mg}$ equivalent chlorogenic acid (EAC) per $100 \mathrm{~g} \mathrm{FM}^{-1}$ in purple fleshed tubers and from 78.30 to $129.46 \mathrm{mg}$ EAC per $100 \mathrm{~g} \mathrm{FM}^{-1}$ in red fleshed tubers showing less variation among clones compared to the anthocyanin content and absence of significant influence of the environment. The well-pigmented purple fleshed clones, C2715-22-09, C2715-01-09, C2743-01-09 and C272122-09 constituted the upper group, with concentrations above $145 \mathrm{mg}$ EAC per $100 \mathrm{~g} \mathrm{FM}^{-1}$. The cultivar BRS Ana, a white fleshed potato and clones C271807-09, C2722-12-09 and C2715-08-09 showed the lowest concentrations of phenolic compounds, varying between 63.73 and $85.20 \mathrm{mg}$ EAC per $100 \mathrm{~g}$ $\mathrm{FM}^{-1}$.

The well-pigmented purple fleshed clones that stood out for anthocyanins and phenolic compounds showed higher antioxidant capacity, with values above 1,900 $\mu \mathrm{g}$ trolox equivalent per $\mathrm{g} \mathrm{FM}^{-1}$. The cultivar BRS Ana and the light yellow fleshed clone C2715-08-09 had the lowest antioxidant capacity, varying from 308.90 to $478.50 \mu \mathrm{g}$ trolox equivalent per $\mathrm{g}$ $\mathrm{FM}^{-1}$, respectively. Considering the 2014 and 2015 data, significant (p $\leq 0.01$ ) positive correlations (Pearson), between the antioxidant activity and the concentration of anthocyanins $(r=0.81)$ and phenolic compounds $(\mathrm{r}=0.92)$, were found in this study, indicating that these bioactive compounds are the main responsible for the antioxidant capacity in red and purple potatoes, as reported by other authors (Valcarcel et al., 2015; Tierno et al., 2016). In potatoes with a white/cream fleshed color and their variants, the main responsible for the antioxidant activity are phenolic acids and flavonoids, subgroups belonging to the phenolic compounds (Brown, 2005). 
Table 2. Flesh color, means of concentration of anthocyanins, total phenolic compounds and total antioxidant activity in the autumn crops, 2014 and 2015; total carotenoids concentration in the autumn crop season 2014 and flesh color parameters $\left(\mathrm{L}^{*}, \mathrm{C}^{*}\right.$ and $\left.\mathrm{h}^{\circ}\right)$ in the autumn crop 2015, of 12 colored flesh potato clones and one conventional cultivar. Pelotas, Embrapa, 2020.

\begin{tabular}{|c|c|c|c|c|c|c|c|c|c|}
\hline \multirow{2}{*}{ Clone/cultivar } & \multirow{2}{*}{ Flesh color } & \multicolumn{2}{|c|}{ Anthocyanins $^{1}$} & \multirow{2}{*}{$\begin{array}{c}\text { Phenolic } \\
\text { compounds }{ }^{2}\end{array}$} & \multirow{2}{*}{$\begin{array}{c}\text { Antioxidant } \\
\text { activity }^{3}\end{array}$} & \multirow{2}{*}{ Carotenoids $^{4}$} & \multirow{2}{*}{$\mathbf{L}^{*}$} & \multirow{2}{*}{$C^{*}$} & \multirow{2}{*}{$\mathbf{h}^{\circ}$} \\
\hline & & 2014 & 2015 & & & & & & \\
\hline C2715-22-09 & Purple & $110.07 \mathrm{a}^{5}$ & $45.12 \mathrm{~b}$ & $145.24 \mathrm{a}$ & $1922.73 \mathrm{a}$ & 0.54 & $41.54 \mathrm{f}$ & $12.20 \mathrm{f}$ & $354.28 \mathrm{a}$ \\
\hline C2715-01-09 & Purple & $93.79 \mathrm{a}$ & $64.47 \mathrm{a}$ & $160.15 \mathrm{a}$ & $2249.30 \mathrm{a}$ & 0.57 & $30.82 \mathrm{~h}$ & $11.67 \mathrm{f}$ & $352.81 \mathrm{a}$ \\
\hline C2743-01-09 & Purple & $89.09 \mathrm{a}$ & $75.31 \mathrm{a}$ & $152.98 \mathrm{a}$ & $2106.29 \mathrm{a}$ & 0.61 & $33.43 \mathrm{~h}$ & $12.98 \mathrm{f}$ & $355.19 \mathrm{a}$ \\
\hline C2721-22-09 & Purple & $88.02 \mathrm{a}$ & $57.92 \mathrm{a}$ & $145.78 \mathrm{a}$ & $1908.34 \mathrm{a}$ & 0.67 & $31.38 \mathrm{~h}$ & $12.87 \mathrm{f}$ & $353.66 \mathrm{a}$ \\
\hline C2718-24-09 & Purple & $62.49 \mathrm{~b}$ & $43.48 \mathrm{~b}$ & & & & $32.71 \mathrm{~h}$ & $12.21 \mathrm{f}$ & $354.90 \mathrm{a}$ \\
\hline C2743-16-09 & $\begin{array}{l}\text { Red interspersed } \\
\text { with white }\end{array}$ & $55.74 \mathrm{~b}$ & $31.98 \mathrm{~b}$ & $129.46 \mathrm{~b}$ & $1422.00 \mathrm{~b}$ & 0.33 & $53.33 \mathrm{~d}$ & $18.75 \mathrm{~d}$ & $24.95 \mathrm{e}$ \\
\hline C2719-11-09 & $\begin{array}{l}\text { Purple interspersed } \\
\text { with white }\end{array}$ & $55.10 \mathrm{~b}$ & $39.68 \mathrm{~b}$ & $136.21 \mathrm{~b}$ & $1610.17 \mathrm{~b}$ & 0.41 & $36.90 \mathrm{~g}$ & 15 & $88 \mathrm{a}$ \\
\hline 2717-04-09 & $\begin{array}{l}\text { Purple int } \\
\text { with white }\end{array}$ & $46.64 \mathrm{~b}$ & $22.22 \mathrm{c}$ & $116.03 \mathrm{~b}$ & $1040.73 \mathrm{c}$ & 0.45 & $45.32 \mathrm{e}$ & 12.5 & $353.32 \mathrm{a}$ \\
\hline C2718-07-09 & $\begin{array}{l}\text { Cream interspersed } \\
\text { with red }\end{array}$ & $15.41 \mathrm{c}$ & $5.80 \mathrm{e}$ & $85.20 \mathrm{c}$ & $723.28 \mathrm{c}$ & 0.48 & $65.60 \mathrm{~b}$ & $26.22 \mathrm{~b}$ & $95.09 \mathrm{~b}$ \\
\hline C2743-09-09 & $\begin{array}{l}\text { White interspersed } \\
\text { with purple }\end{array}$ & $14.47 \mathrm{c}$ & $12.01 \mathrm{~d}$ & $115.92 \mathrm{~b}$ & $976.69 \mathrm{c}$ & 0.25 & $60.93 \mathrm{c}$ & $10.61 \mathrm{f}$ & $58.72 \mathrm{~d}$ \\
\hline C2722-12-09 & $\begin{array}{l}\text { Cream interspersed } \\
\text { with red }\end{array}$ & $10.41 \mathrm{~d}$ & $12.14 \mathrm{~d}$ & $78.30 \mathrm{c}$ & $734.51 \mathrm{c}$ & 0.63 & $63.26 \mathrm{c}$ & $20.86 \mathrm{c}$ & $81.57 \mathrm{c}$ \\
\hline C2715-08-09 & Light yellow & $7.10 \mathrm{e}$ & $1.87 \mathrm{f}$ & $81.98 \mathrm{c}$ & $478.50 \mathrm{~d}$ & 0.65 & $69.83 \mathrm{a}$ & $31.31 \mathrm{a}$ & $100.33 \mathrm{~b}$ \\
\hline BRS Ana & White & $2.90 \mathrm{f}$ & $5.47 \mathrm{e}$ & $63.73 \mathrm{c}$ & $308.90 \mathrm{~d}$ & 0.46 & $71.93 \mathrm{a}$ & $23.90 \mathrm{~b}$ & $100.65 \mathrm{~b}$ \\
\hline Mean & - & 50.10 & 32.11 & 118.43 & 1292.27 & 0.51 & 49.00 & 17.08 & 225.56 \\
\hline CV (\%) & - & 5.93 & 6.35 & 9.53 & 19.39 & 30.69 & 4.32 & 8.57 & 1.89 \\
\hline
\end{tabular}

${ }^{1} \mathrm{mg}$ cyanidyn-3-glucoside per $100 \mathrm{~g}$ fresh mass ${ }^{-1}\left(\mathrm{FM}^{-1}\right) ;{ }^{2} \mathrm{mg}$ of equivalents in chlorogenic acid per $100 \mathrm{~g} \mathrm{FM}^{-1} ;{ }^{3} \mu \mathrm{g}$ of equivalent of trolox per $\mathrm{g} \mathrm{FM}^{-1} ;{ }^{4} \mathrm{mg}$ of equivalent in $\beta$-carotene per $100 \mathrm{~g} \mathrm{FM}^{-1} ;{ }^{5}$ Means followed by same letters in the column, belong to the same group by Scott-Knott test, $5 \%$ probability.

Regarding carotenoids, the nondetected variability is due to the low concentrations of this compound in the cream and light yellow fleshed clones. Brown et al. (2005) found carotenoid concentrations in red/purple fleshed clones similar to concentrations in white fleshed clones, ranging from 35 to 178 $\mu \mathrm{g}$ per $100 \mathrm{~g} \mathrm{FM}^{-1}$ and from 40 to $101 \mu \mathrm{g}$ per $100 \mathrm{~g} \mathrm{FM}^{-1}$, respectively. In yellow fleshed potatoes, Fernandez-Orozco et al. (2013) found total carotenoid concentrations ranging from 54 to 1,551 $\mu \mathrm{g}$ per $100 \mathrm{~g}$ dry mass $^{-1}$. Therefore, to create cultivars with more intense yellow fleshed available, germplasm with higher concentrations of this compound must be introgressed.

Regarding the flesh color parameters $\left(L^{*}, C^{*}\right.$ and $\left.h^{\circ}\right)$, clones with purple and purple flesh interspersed with white, C2717-04-09, C2715-22-09,
C2719-11-09, C2743 -01-09, C271824-09, C2721-22-09 and C2715-01-09, presented tonal angles $\left(\mathrm{h}^{\circ}\right)$ in the fourth quadrant of the Hunter colored solid (blue/red) (Table 2). The higher values of the Hue angle, combined with lower saturation $\left(\mathrm{C}^{*}\right)$, indicate a more opaque purple color, which is consistent with the color observed in these clones.

Glucose content, dry mass content and chip color

The joint analysis of variance revealed significance $(p \leq 0.05)$ for the genotype $\mathrm{x}$ year interaction for glucose content. Thus, the performance of the clones was evaluated separately in each crop year. For dry mass percentage and chip color, traits assessed in 2015, the individual variance analysis was performed, which revealed a significant difference among genotypes only for dry mass.
The requirements for tubers intended for processing are the ability to produce light-colored, tasty and crunchy fried products. The color of the processed products is related to the content of reducing sugars (Marquez \& Añon, 1986), while the crispness is related to the percentage of dry mass of the tubers (Genet, 1992). In potato breeding programs, the evaluation of the chip color is a quick and practical method that serves as an indication of the reducing sugar content of the clones. However, since in colored flesh genotypes, the purple color of the flesh mask brown pigments (melanoidins) formed by the Maillard reaction, the glucose content is more effective in assessing the clones' suitability for use.

About glucose means, three groups were formed in 2014 (Table 3). Clones C2715-22-09, C2718-07-09, C2743- 
Table 3. Means of glucose content for the autumn crops 2014 and 2015, of dry matter (\%) for the autumn crop 2014 and chip color for the autumn crop 2015, of 12 colored flesh potato clones and one conventional cultivar. Pelotas, Embrapa, 2020.

\begin{tabular}{|c|c|c|c|c|}
\hline \multirow{2}{*}{ Clone/cultivar } & \multicolumn{2}{|c|}{ Glucose (\%) } & \multirow{2}{*}{ Dry matter (\%) } & \multirow{2}{*}{ Chip color } \\
\hline & 2014 & 2015 & & \\
\hline BRS Ana & $0.073 \mathrm{a}^{2}$ & $0.030 \mathrm{~b}$ & $23.0 \mathrm{a}$ & 6.0 \\
\hline C2715-01-09 & $0.065 \mathrm{a}$ & $0.022 \mathrm{~b}$ & $22.8 \mathrm{a}$ & 5.1 \\
\hline C2715-08-09 & $0.061 \mathrm{a}$ & $0.064 \mathrm{a}$ & $21.9 \mathrm{a}$ & 3.9 \\
\hline C2718-24-09 & $0.054 \mathrm{a}$ & $0.014 \mathrm{~b}$ & $20.9 \mathrm{~b}$ & 5.3 \\
\hline C2719-11-09 & $0.032 \mathrm{~b}$ & $0.024 \mathrm{~b}$ & $20.9 \mathrm{~b}$ & 6.2 \\
\hline C2721-22-09 & $0.030 \mathrm{~b}$ & $0.015 \mathrm{~b}$ & $20.6 \mathrm{~b}$ & 4.9 \\
\hline C2722-12-09 & $0.026 \mathrm{~b}$ & $0.066 \mathrm{a}$ & $20.2 \mathrm{~b}$ & 3.0 \\
\hline C2743-01-09 & $0.023 \mathrm{~b}$ & $0.019 \mathrm{~b}$ & $22.9 \mathrm{a}$ & 4.6 \\
\hline C2715-22-09 & $0.020 \mathrm{c}$ & $0.020 \mathrm{~b}$ & $22.7 \mathrm{a}$ & 5.2 \\
\hline C2718-07-09 & $0.015 \mathrm{c}$ & $0.015 \mathrm{~b}$ & $22.1 \mathrm{a}$ & 4.7 \\
\hline C2743-09-09 & $0.015 \mathrm{c}$ & $0.019 \mathrm{~b}$ & $22.7 \mathrm{a}$ & 3.9 \\
\hline C2743-16-09 & $0.015 \mathrm{c}$ & $0.018 \mathrm{~b}$ & $23.9 \mathrm{a}$ & 2.8 \\
\hline C2717-04-09 & $0.014 \mathrm{c}$ & $0.027 \mathrm{~b}$ & $21.1 \mathrm{~b}$ & 4.8 \\
\hline Mean & 0.034 & 0.027 & 22.0 & 4.7 \\
\hline CV (\%) & 25.37 & 28.18 & 4.81 & 26.38 \\
\hline
\end{tabular}

${ }^{1}$ Notes close to 1 are desirable and assigned to the light color and 9 to the dark color; ${ }^{2}$ Means followed by same letters in the column, belong to the same group by Scott-Knott test, 5\% probability.

09-09, C2743-16-09 and C2717-04-09 constituted the group with the lowest glucose levels, ranging between 0.014 and $0.020 \%$. The cultivar BRS Ana and clones C2715-01-09, C2715-08-09 and C2718-24-09 showed the highest glucose levels, ranging from 0.054 to $0.073 \%$. In 2015 , except clones C2715-08-09 and C2722-12-09, the other clones had glucose levels similar to the check BRS Ana, ranging from 0.014 to $0.030 \%$. Considering that the acceptable glucose content in tubers for chipping is below $0.035 \%$ of fresh tuber mass (Stark et al., 2003), except for the group of clones with the highest levels in both 2014 and 2015 years, the other clones have the required content and can therefore be used for chipping. In addition to glucose level requirement, the colored flesh clones had a short oval tuber shape, suitable chipping.

In relation to dry mass percentage, the clones formed two groups (Table $3)$. The upper group was composed by the cultivar BRS Ana and clones C2715-01-09, C2715-08-09, C274301-09, C2715-22-09, C2718-07-09, C2743-09-09 and C2743-16-09, which comprised contents between 21.9 to $23.9 \%$. The other clones showed dry mass percentage still above $20 \%$. In order to that the processed product have good texture, crispness and high industrial yield, the percentage of dry mass of the tubers must be between 20 and 24\% (Love, 2000). This way, it is expected that all clones have good processing quality in this regard.

Considering that the potato is an important staple food, the availability of colored fleshed cultivars, rich in antioxidants, is an attractive novelty and interesting alternative to traditional products and may play an important role for the Brazilian potato chain, as well as for consumer health. In the latter, showing potential to mitigate factors that lead to cancer and heart disease (Kaspar et al., 2013).

Clones C2715-01-09, C272122-09 and C2743-01-09 have high concentrations of bioactive compounds and high antioxidant capacity, in addition to reasonable processing quality traits and yield potential. Clone C2743-09-09 is the most productive and has attributes for frying; however, it has lower levels of bioactive compounds and moderate antioxidant activity when compared to completely purple clones.

\section{ACKNOWLEDGMENTS}

The study was carried out with the support of the Coordination for the Improvement of Higher Education Personnel, Brazil (CAPES), financing code 001 .

\section{REFERENCES}

AOAC. 1995. Official methods of analysis of the Association of Official Analytical Chemists. AOAC Official Method 934.06, Chapter 37, Arlington: AOAC $\mathrm{p} 4$.

BISOGNIN, DA; MÜLLER, DR; STRECK, NA; ANDRIOLO, JL; SAUSEN, D. 2008. Desenvolvimento e rendimento de clones de batata na primavera e no outono. Pesquisa Agropecuária Brasileira 43: 699-705.

BRAND-WILLIAMS, W; CUVELIER, ME; BERSET, C. 1995. Use of a free radical method to evaluate antioxidant activity. Lebensmittel-Wissenschaft und Technologie 28: 25-30.

BROWN, CR. 2005. Antioxidants in potato. American Journal of Potato Research 82: 163-172.

BROWN, CR; CULLEY, D; YANG, CP; DURST, R; WROLSTAD, R. 2005.Variation of anthocyanin and carotenoid contents and associated antioxidant values in potato breeding lines. Journal of the American Society for Horticultural Science 130: 174180.

BROWN, CR; EDWARDS, CG; YANG, CP; DEAN, BB. 1993. Orange flesh trait in potato: Inheritance and carotenoid content. Journal of the American Society for Horticultural Science 118: $145-150$.

CIP - International Potato Center. 2018. Potato facts and figures. Available at: https://cipotato. org/crops/potato/potato-facts-and-figures/. Assessed November 15, 2018.

DOUCHES, D; MAAS, D; JASTRZEBSKI, K; CHASE, RW. 1996. Assessment of potato breeding progress in the USA over the last Century. Crop Science 36: 1544-1552.

FERNANDEZ-OROZCO, R; GALLARDOGUERRERO, L; HOIRNERO-MÉNDEZ, D. 2013. Carotenoid profiling in tubers of different potato (Solanum sp) cultivars: Accumulation of carotenoids mediated by xanthophyll esterification. Food Chemistry 141: 2864-2872.

FULEKI, T; FRANCIS, FJ. 1968. Quantitative methods for anthocyanins. 1. Extraction and determination of total anthocyanin in cranberries. Journal of Food Science 33: 72-77.

GENET, RA. 1992. Potatoes - the quest for 
processing quality. Proceedings Agronomy Society of New Zealand 22: 3-7.

IBGE - Instituto Brasileiro de Geografia e Estatística. 2018. Levantamento sistemático da produção agrícola. Available at: https:// www.ibge.gov.br/estatisticas-novoportal/ economicas/agricultura-e-pecuaria/9201levantamento-sistematico-da-producaoagricola.html?edicao $=19941 \& \mathrm{t}=$ resultados . Assessed November 15, 2018.

KASPAR, KL; PARK, JS; BROWN, CR; MATHISON, BD; NAVARRE, DA; CHEW, BP. 2013. Pigmented potato consumption improves immune response in men: a randomized controlled trial. American Journal of Advanced Food Science and Technology 1: $15-25$.

LACHMAN, J; HAMOUZ, K; ORSÁK, M. 2016. Colored potatoes. In: SINGH, J; KAUR, L (eds). Advances in Potato Chemistry and Technology. $2^{\text {nd }}$ ed. New Zealand: Elsevier. p.249-281.

LIU, RH. 2013. Health-promoting components of fruits and vegetables in the diet. Advances in Nutrition 4: 384S-392S.

LOVE, SL. 2000. Important characteristics in breeding processing potatoes. In: WORLD POTATO CONGRESS, 4., Proceedings... Amsterdam: Wageningen Pres. p. 261-266.

MARQUEZ, G; AÑON, MC. 1986. Influence of reducing sugars and amino acids in the color development of fried potatoes. Journal of Food Science 51: 157-160.

NAVARRE, DA; PAYYAVULA, RS; SHAKYA, R;
KNOWLES, NR; PILLAI, SS. 2013.Changes in potato phenylpropanoid metabolism during tuber development. Plant Physiology and Biochemistry 65:89-101.

NAVARRE, DA; SHAKYA, R; HELLMANN, H. 2016. Vitamins, phytonutrients and minerals in potato. In: SINGH, J; KAUR, L (eds). Advances in Potato Chemistry and Technology. $2^{\text {nd }}$ ed. New Zealand: Elsevier. p. 117-166.

NELSON, N. 1944. A photometric adaptation of the Somogyi method for the determination of glucose. Journal of Biological Chemistry 153: 375-380.

PAYYAVULA, RS; NAVARRE, DA; KUHL, J; PANTOJA, A. 2013. Developmental effects on phenolic, flavonol, anthocyanin and carotenoid metabolites and gene expression in potatoes. Journal of Agricultural and Food Chemistry 61: 7357-7365.

REDDIVARI, L; VANAMALA, J; CHINTHARLAPALLI, S; SAFE, SH; MILLER, JC. 2007. Anthocyanin fraction from potato extracts is cytotoxic to prostate cancer cells through of caspase-dependent and caspase-independent pathways. Carcinogenesis 28: 2227-2235.

STARK, JC; OLSEN, N; KLEINKOPF, GE; LOVE, SL. 2003. Tuber quality. In: STARK, JC; LOVE, SL. Potato Production Systems. Aberdeen: University of Idaho. p.329-343.

SULC, M; KOTÍKOVÁ, Z; PAZNOCHT, L; PIVEC, V; HAMOUZ, K; LACHMAN, J. 2017. Changes in anthocyanidin levels during the maturation of color-fleshed potato (Solanum tuberosum L.) tubers. Food
Chemistry 237: 981-988.

SWAIN, T; HILLIS, WE. 1959. The phenolic constituents of Prunus domestica L. - The quantitative analysis of phenolic constituents. Journal of Science and Food Agriculture 10: 63-68.

TALCOTT, TS; HOWARD, RL. 1999. Phenolic autoxidation is responsible for color degradation in processed carrot puree. Journal of Agriculture and Food Chemistry 47: 2109-2115.

THOMPSON, MD; THOMPSON, HJ; MCGINLEY, JN; NEIL, ES; RUSH, DK; HOLM, DG; STUSHNOFF, C. 2009. Functional food characteristics of potato cultivars (Solanum tuberosum L.): phytochemical composition and inhibition of 1-methyl-1-nitrosourea induced breast cancer in rats. Journal of Food Composition and Analysis 22:571-576.

TIERNO, R; LÓPEZ, A; RIGA, P; ARAZURI, S; JARÉN, C; BENEDICTO, L; RUIZ GALARRETA, JI. 2016. Phytochemicals determination and classification in purple and red fleshed potato tubers by analytical methods and near infrared spectroscopy. Journal of the Science of Food and Agriculture 96: 1888-1899.

VALCARCEL, J; REILLY, K; GAFFNEY, M; O'BRIEN, NM. 2015. Antioxidant activity, total phenolic and total flavonoid content in sixty varieties of potato (Solanum tuberosum L.) grown in Ireland. Potato Research 58: 221-244. 